\title{
Miniature Automatic Watering System of Ornamental Plant at Permanent Seedbed of Central Management of Regional River Flow (BPDAS) Palu-Poso Using Microcontroller Arduino-Uno
}

\author{
Merry Subito ${ }^{1 *}$, Sitti Nurrahmi ${ }^{1}$ and Aidynal Mustari ${ }^{2}$ \\ ${ }^{1}$ Department of Electrical Engineering, Faculty of Engineering, Tadulako University, Palu 94111, \\ Indonesia.
}

\begin{abstract}
The results of the research carried out were successful in making the Miniature automatic watering system designed using Arduino UNO as a brain control system, DHT22 sensors to measure temperature and humidity environment, RTC module as a time saver, water pump and DC motor used for the watering mecanism. After testing all the tools and sensors, the instrument can be run well and normally. Watering done on the morning (08:00 wita) using the RTC as the reservoir time, the RTC will inform the arduino so arduino will command to a motorcycle do a watering. When air temperature around detected more than $18^{\circ} \mathrm{C}$ and soil humidity less than 60 $\%$ then the system will automatically did watering over past 3 minutes. So that automatic watering system can be used to help out watering an ornamental plant based on sensors detected related to temperature and soil humidity at the green house.
\end{abstract}

\section{Introduction}

Every plant having different water needs. Watering plants are a monotonous occupation and performed with manual way in particular time. The problem when watering the plant manually relating to the quantity of water needed for plants. There is a plant that is sensitive to water, especially an ornamental such as orchidaceous and others. In a day, if the sensitive plants not watering, it made the plants wilting [4]. The less or excessive in watering plants can cause dry or rotten. It took an apparatus that can detect the water level and soil humidity, to perform the function of sprinkling water in accordance with the needs of plants [9]. Based on these problems, the researchers devised an apparatus which can be used to flush automatically plant that function to detect the soil humidity and air temperature as well as performing the functions of watering according to the need for water required by plant [4].

\footnotetext{
*Corresponding author: mery_subito@yahoo.com
} 


\section{Method}

Research on automatics watering system of ornamental plants at green house based on microcontroller Arduino UNO has been started in April 2018 - September 2018 and located in permanent seedbed of central management of regional river flow (BPDAS) Palu - Poso's green house (https://goo.gl/maps/c9bC4Fgqum8kHY9y5) and condition of permanent nursery watering system in BPDAS Palu-Poso still said manually because still need hose length for watering that used by human resources, It is the main problems faced by the green house administrator. As shown in Fig. 1 when the team conducted the survey.

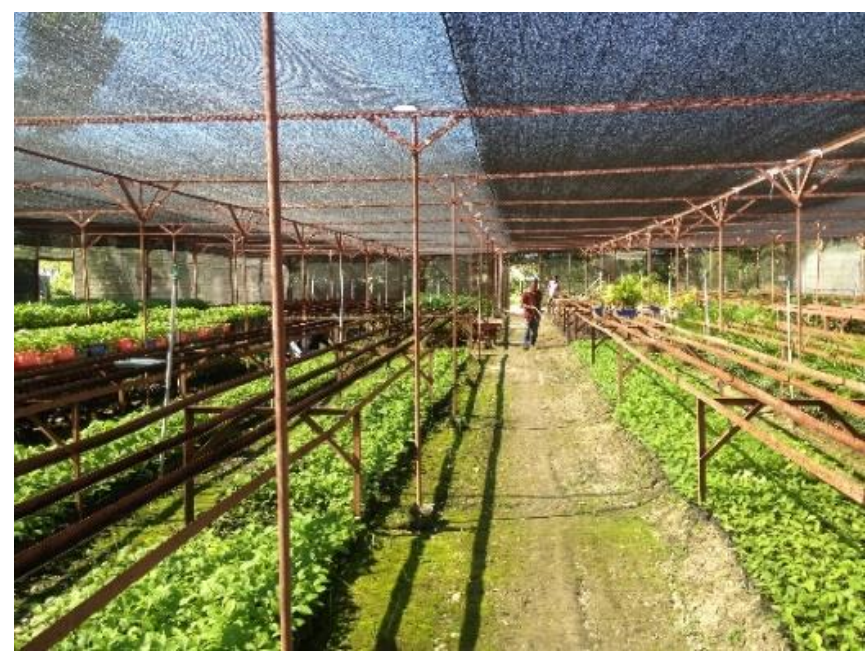

Fig. 1. Existing condition of permanent nursery watering system in BPDAS Palu-Poso

\subsection{Materials}

For materials is divided into 2 categories ; Hardware and software. For Hardware : 1) electronics components include microcontroller Arduino UNO, DHT22 sensor, DC motor, RTC DS3231 module, LCD (Liquid Crystal Display), LED (light emiting diode), switch , pcb board, relay module, and other electronics component ( resistor , capasitor, transistor, etc ); 2 ) power supply; 3) water pumps; 4) tin; 5) wires; 6) ultraviolet plastics; 7) paralone pipe; 8) nozzle sprayer ; 9) pipe glue; 10 ) water collection; 11) mild steel; 12 ) Bolts and nuts. For Software: Arduino IDE, Deep trace 2.3, Proteus Professional.v8.0, Google SketchUp 2016, and Livewire.

\subsection{Tools}

The tools used are Laptop, solder, multimeter, gurinda, an electric drill, writing tools, and toolset. This research is a qualitative research based on experiment, that is manufactured an instrument that could serve as an ornamental plant watering system based ArduinoUNO. Drafting instrument started by making block diagram used as a reference to know the concept of ornamental plant watering system based arduino uno. Block diagram design is presented in Fig. 2. 


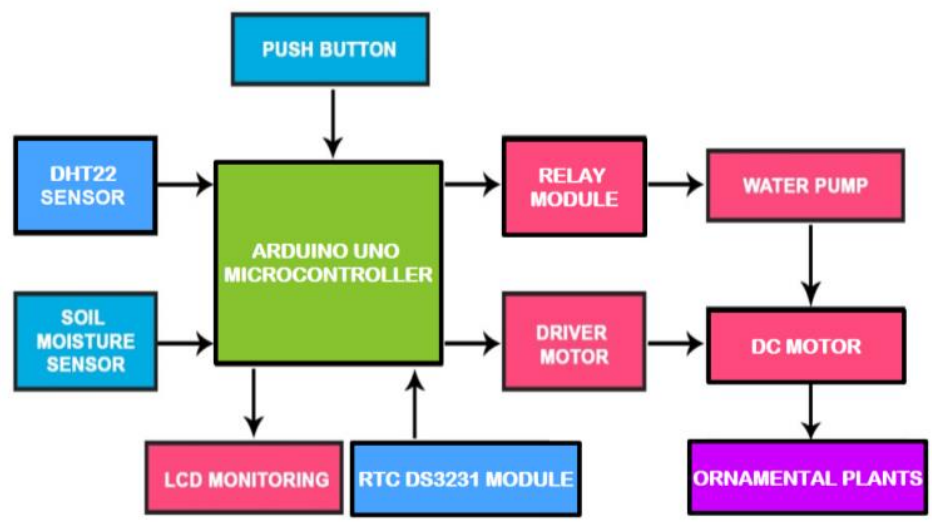

Fig. 2. Block diagram system design

In block diagram there are input components, output components, and Arduiono UNO as brains of a system. All the block diagrams consist of:

1. DHT22 sensors serves to detect temperatures and humidity around the ornamental plant, then the output will be input to Arduino UNO.

2. Soil humidity sensors to detect the water level on the ground, then the output will entered to Arduino UNO.

3. Arduino UNO is microcontroller or as a brains of system, that serves to processing the data sent by censorship, next arduino uno will perform value or data obtained from LCD then compares with particular data and taken action (turn on/off the water pump).

4. Relay serves as an intermediary between Arduino UNO that have voltage 5-12 V DC and water pump.

5. RTC ( real time clock ) serves to counting time, ranging from seconds, minutes, hours, date, moon, and years.

6. Water pump used to pump water at the shelter and then blow up to ornamental plants.

7. DC Motor serves to move the sprinklers hose right and left so watering is more equal.

8. Display serves to display the result from sensor data that measurable.

9. Push button used to turn on/off the instrument.

Other than a block diagram, also made system design as a general picture of watering system of ornamental plant-based Arduino UNO, that presented in Fig. 3.

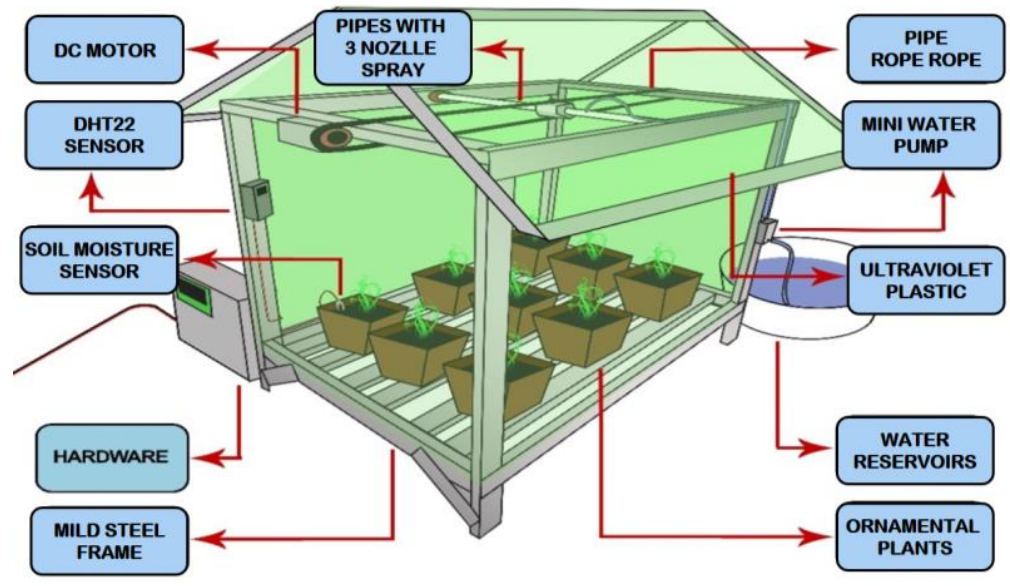

Fig. 3. System design automatic watering system of ornamental plant 


\section{Result and Discussion}

Has been built an automatic watering system of ornamental plant at permanent seedbed of central management of regional river flow (BPDAS) Palu - Poso's green house use microcontroller Arduino UNO as the brain of the system. The results showed all the instrument work well according to design made. And the instrument of miniature automatic watering system as shown in Fig. 4.

\section{1) LCD testing}

The aim of LCD testing is to obtaining character parameters on LCD.Testing done by program character or writing to displayed on LCD screen.

2) Air temperature and soil humidity sensors testing

The aim of air temperature testing is to see if temperature sensors DHT22 work well or not. It testing in the morning, noon, afternoon, and night. Table 1 showed the result of air temperature testing.

Table 1. Air temperature sensors testing

\begin{tabular}{|c|c|}
\hline Time & DHT22 $\left({ }^{\circ} \mathbf{C}\right)$ \\
\hline Morning & 30 \\
\hline Noon & 37 \\
\hline Afternoon & 33 \\
\hline Night & 28 \\
\hline
\end{tabular}

Then doing soil humidity sensors testing with thrust the sensors into the ground on ornamental plants. The result of soil humidity sensors can be seen in Table 2 .

Table 2. Soil humidity sensors testing

\begin{tabular}{|c|c|}
\hline Value of watering (ml) & Soil Humidity Sensor (\%) \\
\hline 20 & 5 \\
\hline 30 & 24 \\
\hline 40 & 45 \\
\hline 50 & 57 \\
\hline 60 & 85 \\
\hline
\end{tabular}

3) Watering pump testing

Pump testing doing to see whether the pump can work right or not. This testing carried out by giving cammands from Arduino into the pump as a high signal so pump running and watering the plants.

4) RTC testing

RTC testing done by making the program and displayed the time on LCD screen that future will be given information to arduino when will doing the watering.

After testing the tools and sensors obtained that the instrument can be running good and properly. Testing is carried on a prototype of green house that has been made. This automatic watering system created by using arduino uno as system controller that put together with other electronic devices and sensor-sensor that supports system. The instrument of automatics watering system can be seen in Fig. 4.

At the time when instrument ignited, automatically all sensors detect and displays the time, air temperature, and soil humidity on LCD screen. Watering doing in the morning (08 $: 00 \mathrm{am}$ ). The RTC as a reservoir time will giving information to arduino so that arduino will commands to a motor for watering the plants. Watering also doing when the air temperature and the soil humidity around the ornamental plants are $18^{\circ} \mathrm{C}$ and $60 \%$. Watering is currently active characterized by using LED lamp indicators a bright red colour. 


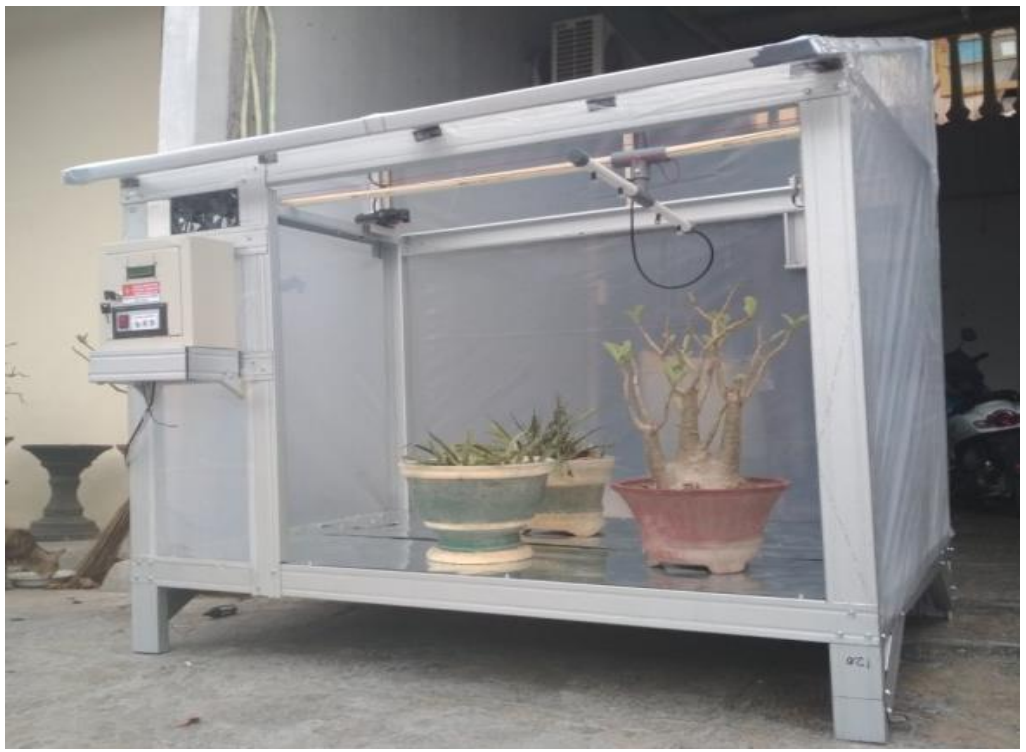

Fig. 4. The instrument of automatics watering system

Watering doing for 3 minutes. The series of automatics watering system can be seen in Fig. 5.

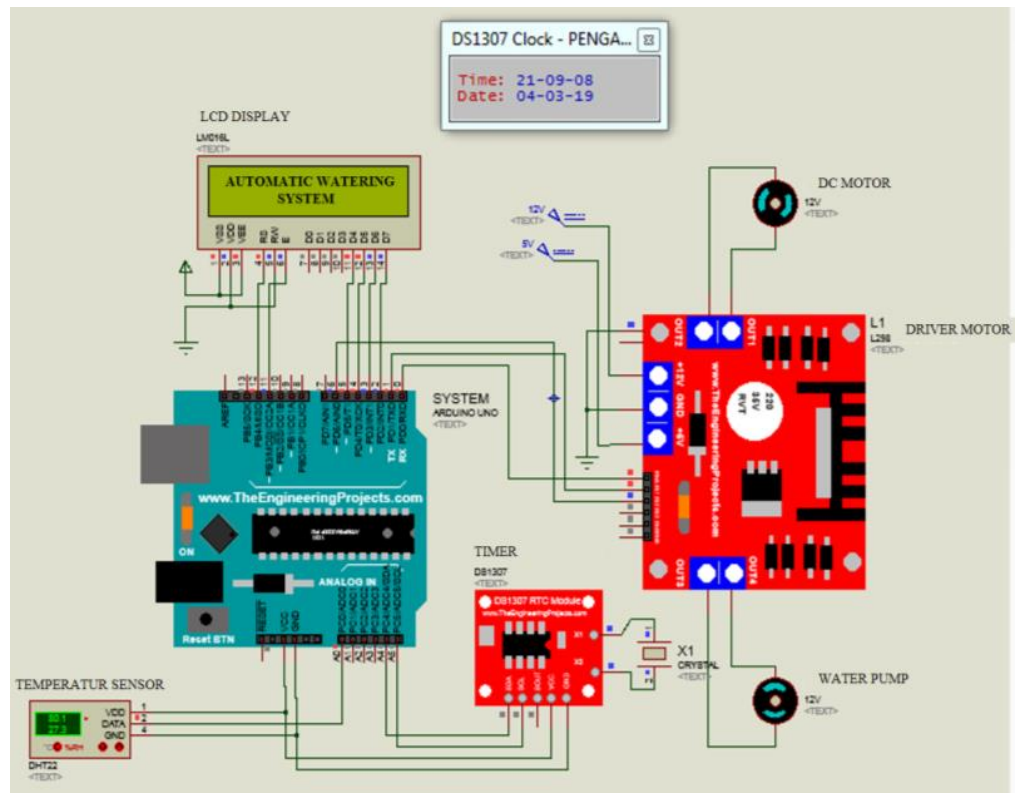

Fig. 5. The schematics of miniature automatics watering system of ornamental plants.

There is the flowchart of automatics watering system that showed in Fig. 6. 


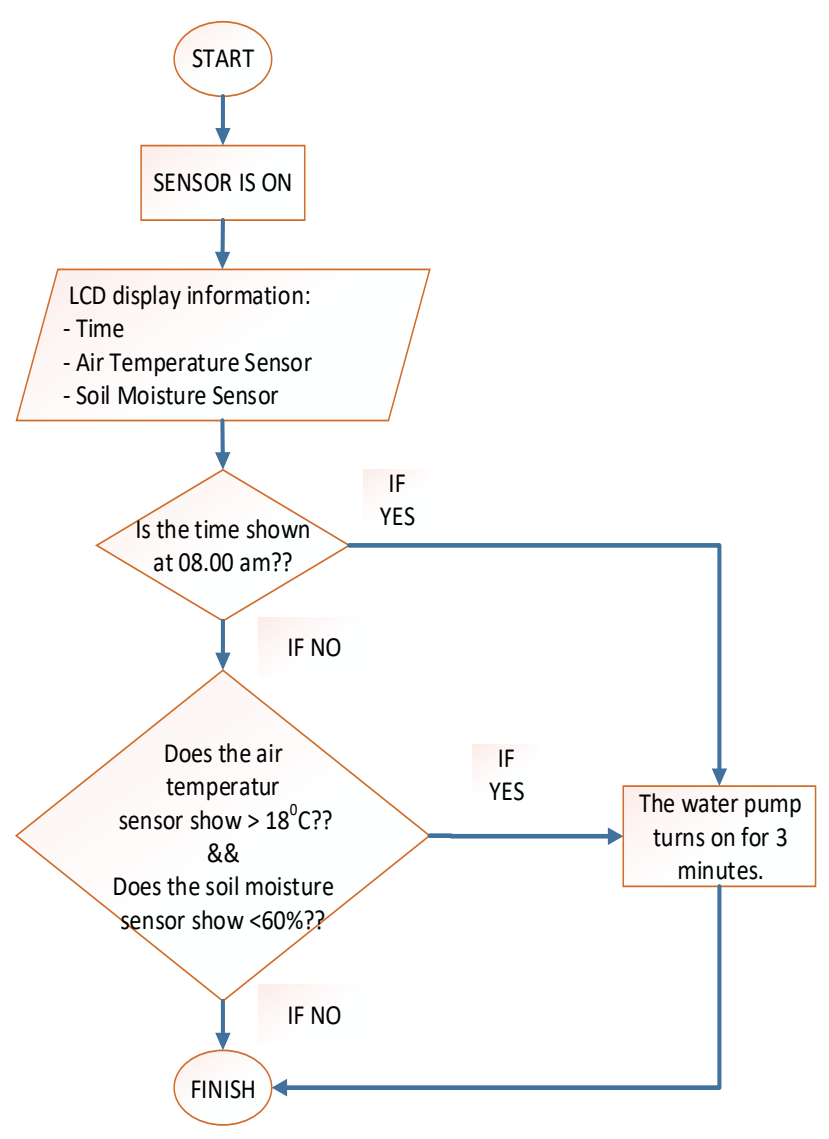

Fig. 6. Flowchart of automatics watering system of ornamental plant

\section{Conclusion}

Has been done research about automatics watering system of ornamental plant at permanent seedbed Of central management of regional river flow (BPDAS) Palu - Poso using microcontroller Arduino-UNO. From this research that the automatic watering system have been successfully made using arduino uno as a control system series with DHT22 sensors that serves to inform the temperatures and humidity in miniature green house that has been created. The parameters occupied in doing automatic watering system are time, temperature and humidity who appeared on miniature green house's LCD. Watering doing in the morning $(08: 00 \mathrm{am})$ by using the RTC components as a reservoir time, the RTC will inform the arduino so arduino will give commands to motor to do a watering. And also when airtemperature detected around the plant more than $18^{\circ} \mathrm{C}$ and soil humidity less than $60 \%$ then the system will automatically do watering. Watering is currently active characterized by using LED lamp indicators a bright red color. Watering doing for 3 minutes.

\section{References}

1. E. B. Setiawan, http://vas bunga.blogspot.co.id/2009/08/budidaya-tanaman-anggrek. html, (2009) 
2. H. Abbas, R. Syam, B. Jaelani, Proc.Seminar Nasional Tahunan Teknik Mesin XIV, 26 (2015).

3. H. N. Widhi, H. Winarno, Gema Teknologi, 18, 41-45 (2014)

4. J. M.S. Waworundeng, N.C. Suseno, R.R.Y. Manaha, Seminar Nasional Multi Disiplin Ilmu, 1 (2017)

5. R.R.A.Putra, http://richie-rap.blogspot.co.id/2014/06/sistem-kendali-suhu-dan-kelemba ban.html (2014).

6. S. Ajie, Mengukur suhu dan kelembaban Udara dengan sensor DHT11 dan Arduino, https://saptaji.com/2016/08/10/mengukur-suhu-dan-kelembaban-udara-dengan-sensor-dht11dan-arduino/(2016).

7. B.D. Argo, M. Fadhil, T. Hendrawan, Rancang bangun prototype alat penyiram otomatis dengan sistem timer RTC DS1307 berbasis mikrokontoller Atmegal6 pada Tanaman Aeroponik, Jurusan Keteknikan Pertanian, Universitas Brawijaya, Malang (2015)

8. R. Sevtria, Alat penyiraman tanaman otomatis mengacu pada suhu dan kelembaban tanah dengan menggunakan sensosr DHT22, Jurusan Metrologi dan Instrumentasi, Universitas Sumatera Utara, Medan. (2016)

9. Widiharto, Sistem penyiraman tanaman yang dapat dimonitor dengan komputer dan perangkat mobile, Thesis, Universitas Muhammadiyah Surakarta (2017).

10. R. Syam, Dasar dasar teknik sensor, Makassar (2015) 